\title{
Use of recombinant factor VIla for the prevention and treatment of bleeding in patients without hemophilia: a systematic review and meta-analysis
}

\author{
Yulia Lin MD, Simon Stanworth DPhil, Janet Birchall MB ChB, Carolyn Doree PhD, Christopher Hyde MBBS
}

\begin{abstract}
Background: The benefits and risks of offlabel use of recombinant factor VIla in patients without hemophilia are contested. We performed a systematic review to assess the effectiveness and safety of such use.

Methods: We searched electronic databases including MEDLINE, EMBASE and CENTRAL for randomized controlled trials comparing recombinant factor VIla with placebo in any patient population except those with hemophilia up to January 2010. Eligible articles were assessed for inclusion, data were extracted, and study quality was evaluated. Outcomes included mortality, blood loss, requirements for red blood cell transfusion, number of patients transfused and thromboembolic events.
\end{abstract}

Results: We identified 26 trials: 14 on off-label prophylactic use of recombinant factor VIla $(n=$ 1137) and 12 on off-label therapeutic use ( $n=$ 2538). In the studies on prophylactic use, we

$\mathrm{R}$ ecombinant factor VIIa is a hemostatic agent licensed for the treatment of bleeding in patients with hemophilia who have inhibitors. It is also used off-label for the prevention and treatment of bleeding in patients without hemophilia.

In the Australian and New Zealand Haemostasis Registry, use of recombinant factor VIIa increased to a plateau in 2006 , which was maintained through $2008 .{ }^{1}$ Because only $1 \%$ of the 2700 patients in this registry had a diagnosis of hemophilia, physicians may believe that off-label use of this agent is effective and outweighs the risks. Randomized controlled trials (RCTs) evaluating recombinant factor VIIa have raised concerns about adverse effects, particularly thromboembolic events. ${ }^{2-7}$ These concerns have been supported by passive surveillance reports from the US Food and Drug Administration's Adverse Event Reporting System, which suggest an increased risk among unselected patients. ${ }^{8}$ In addition, although cost is but one component, at a dose of $80 \mu \mathrm{g} / \mathrm{kg}$ for a $70-\mathrm{kg}$ patient, the approximate found no significant difference in mortality or thromboembolic events between the treatment and placebo groups. We found modest benefits favouring recombinant factor VIla in blood loss (weighted mean difference $-276 \mathrm{~mL}, 95 \%$ confidence interval $[\mathrm{Cl}]-411$ to $-141 \mathrm{~mL}$ ), red blood cell transfusion (weighted mean difference $-281 \mathrm{~mL}, 95 \% \mathrm{Cl}-433$ to $-129 \mathrm{~mL}$ ) and number of patients transfused (relative risk $0.71,95 \% \mathrm{Cl} 0.50$ to 0.99 ). In the therapeutic trials, we found a nonsignificant decrease in mortality and a nonsignificant increase in thromboembolic events but no difference in control of bleeding or red blood cell transfusion.

Interpretation: Clinically significant benefits of recombinant factor VIla as a general hemostatic agent in patients without hemophilia remain unproven. Given its potential risks, such use cannot be recommended, and in most cases, it should be restricted to clinical trials.

cost of $5.6 \mathrm{mg}$ of recombinant factor VIIa would be $\$ 6270$ in Canada (Chantal Couture, Canadian Blood Services, Ottawa, Ont.: personal communication, 2010) and $£ 2800$ in the United Kingdom. By contrast, the current cost of one unit of red blood cells is \$419 in Canada (Marcel Leclair, Finance, Canadian Blood Services, Ottawa, Ont.: personal communication, 2010) and $£ 133$ in the United Kingdom (Julie Staves, National Health Service Blood and Transplant, Hertfordshire, UK: personal communication, 2010).

We conducted a systematic review and metaanalysis of the effectiveness and risks of recombinant factor VIIa in patients without hemophilia and assessed the implications of these results for future research.

\section{Methods}

\section{Literature search}

We searched the following bibliographic databases on Jan. 18, 2010: MEDLINE, EMBASE, CENTRAL (The Cochrane Library Issue 4,
Competing interests:

Yulia Lin is a site investigator for a registry on the off-label use of recombinant factor VIIa that is funded by an unrestricted educational grant from Novo Nordisk; she receives no personal financial payments for participation. No competing interests declared by Simon Stanworth, Janet Birchall, Carolyn Doree or Chris Hyde.

This article has been peer reviewed.

Correspondence to: Dr. Yulia Lin; yulia.lin@sunnybrook.ca

CMAJ 2011. DOI:10.1503 /cmaj.100408 
2009), CINAHL, the UK Blood Transfusion and Tissue Transplantation Services Transfusion Evidence Library, LILACS, KoreaMed, IndMed, PakMediNet, mRCT, ClinicalTrials.gov and the World Health Organization's ICTRP Database (Appendix 1, available at www.cmaj.ca/cgi /content/full/cmaj.100408/DC1). The search was not restricted by language, but we included only published, full-text versions of RCTs. We also checked the reference lists of the identified RCTs and recently published systematic reviews. ${ }^{49-13}$

\section{Study selection}

We included RCTs comparing recombinant factor VIIa with no treatment, an alternative treatment or different doses of recombinant factor VIIa in patients without hemophilia. We excluded RCTs involving patients with congenital bleeding disorders or healthy volunteers. Two of us (Y.L. and S.S.) independently screened all of the citations, including the titles and abstracts, and reviewed the full text of citations considered relevant.

\section{Outcomes}

We divided the RCTs into two groups: prophylactic use and therapeutic use. In the prophylactic group, recombinant factor VIIa was given to prevent anticipated bleeding, for example during an operation; in the therapeutic group, the agent was given to treat bleeding that was already established. For the studies of prophylactic use, the outcomes included mortality, total blood loss, use of red blood cell transfusion (measured in millilitres), number of patients receiving transfusions and number of thromboembolic events. Thromboembolic events included any reported arterial event (increased troponin level, myocardial infarction or ischemia, stroke and "other") or venous event (deep vein thrombosis, pulmonary embolus, thrombophlebitis and "other"). For studies of therapeutic use, the same outcomes were used, except control of bleeding was measured instead of total blood loss.

Details on risk of bias (random sequence generation, concealment of allocation, blinding, loss to follow-up and power calculation) were collected. Two of us (Y.L., S.S. or J.B.) independently extracted data using a predesigned form; disagreements were resolved by consensus.

\section{Statistical analysis}

The meta-analysis was conducted using the random-effects model, decided a priori, because of the marked clinical heterogeneity. We performed a subgroup analysis in which low-dose therapy was defined as less than $80 \mu \mathrm{g} / \mathrm{kg}$ and standard or high-dose therapy was defined as $80 \mu \mathrm{g} / \mathrm{kg}$ or more. Because there was minimal difference in results between these groups, we present only combined results.

Data were combined using the MantelHaenszel method for dichotomous outcomes and inverse variance for continuous outcomes. Pooled estimates were reported as relative risks (RRs) for dichotomous data (e.g., mortality) and weighted mean differences for continuous data (e.g., transfusion requirements). A unit of red blood cells was assumed to be $300 \mathrm{~mL}$. Statistical heterogeneity was examined using the $I^{2}$ statistic and visual inspection of graphs. Heterogeneity was explored post hoc using study size ( $<50 \mathrm{v}$. $\geq 50$ patients), concealment of allocation (adequate v. unclear or inadequate) and transfusion protocol (present $\mathrm{v}$. absent).

\section{Results}

We identified 449 records through the literature search, from which 26 RCTs were included in the final analysis (Figure 1). The report by Boffard and coauthors was considered as two separate trials in blunt and penetrating trauma. ${ }^{14}$

\section{Study and patient characteristics}

Of the 26 RCTs, 14 were of the prophylactic use of recombinant factor VIIa, with study samples of 18 to 235 patients (Table 1). (Tables $1-4$ can be found at the end of the article.) The clinical settings included cardiopulmonary bypass surgery, ${ }^{15-18}$ liver biopsy, ${ }^{19}$ hepatic resection, ${ }^{20,21}$ liver transplantation, ${ }^{22-24}$ traumatic pelvic fracture, ${ }^{25}$ spinal surgery ${ }^{26}$ radical prostatectomy ${ }^{27}$ and skin excision following burns. ${ }^{28}$ Dosing regimens varied from a single dose of $5 \mu \mathrm{g} / \mathrm{kg}$ to multiple doses totalling $360 \mu \mathrm{g} / \mathrm{kg} .^{22,26}$ The primary outcomes were predominantly blood loss, ${ }^{25-27}$ red blood cell transfusion $^{16,21-23,27,28}$ and number of patients receiving allogeneic transfusion. ${ }^{15,20,21}$ Protocols for transfusion were reported in 8 of 11 RCTs. The main criterion for excluding patients was prior thromboembolic or vascular disease. Active surveillance for adverse events occurred in five studies. ${ }^{20-23,27}$

Twelve RCTs were of the therapeutic use of recombinant factor VIIa, with sample sizes ranging from 28 to 400 patients (Table 2). The clinical settings included trauma, ${ }^{14}$ cirrhosis with upper gastrointestinal bleeding, ${ }^{29,30}$ bleeding after cardiac surgery, ${ }^{31}$ dengue hemorrhagic fever, ${ }^{32}$ bleeding after hematopoietic stem-cell transplant, ${ }^{33}$ spontaneous intracranial hemorrhage $e^{3,34-36}$ and traumatic intracranial hemorrhage. ${ }^{37}$ Dosing regimens varied from a single dose of $5 \mu \mathrm{g} / \mathrm{kg}^{36}$ to multiple doses totalling $1120 \mu \mathrm{g} / \mathrm{kg} .{ }^{33}$ The primary outcomes included control of bleeding, ${ }^{2,30,32,33,35}$ transfusion requirements, ${ }^{14}$ adverse events $\mathrm{s}^{31,34,36,37}$ and, in one study of intracranial hemorrhage, a clinical com- 
bined outcome of severe disability or death. ${ }^{3} \mathrm{Com}-$ mon exclusion criteria were history of clotting and hemorrhagic diathesis. Transfusion protocols were not required in the studies of intracranial hemorrhage and were described in four of the remaining seven studies; specifically, they were not described in the two trauma studies in which the primary outcome was transfusion requirement. ${ }^{14}$

\section{Study quality}

Overall, most of the 26 RCTs had some potential threats to validity (Table 3), primarily because of the lack of detail provided in the report. Sequence generation was adequate in 13 trials, allocation concealment was adequate in 7 , and blinding was adequate in 16 studies. A power calculation was performed and the target sample size was achieved in only 10 studies. Most of the studies ( 8 of the 14 prophylactic trials and all 12 of the therapeutic studies) were either supported by NovoNordisk (the manufacturer of recombinant factor VIIa) or were coauthored by an employee of NovoNordisk.

\section{Outcomes}

\section{Prophylactic use}

The pooled RR for mortality was $0.82(95 \%$ confidence interval $[\mathrm{CI}] 0.36$ to $1.83 ; I^{2}=0 \%$ ). The individual results from the 13 studies that provided mortality data had a $95 \%$ CI that included 1.0 (Figure 2). Rates of death in the placebo groups were generally low across all studies, the maximum being 3/9. ${ }^{28}$

Eight studies contributed data on blood loss. The pooled weighted mean difference was $-276 \mathrm{~mL}$ ( $276 \mathrm{~mL}$ less blood loss in the recombinant factor VIIa arms; $95 \%$ CI -411 to $-141 \mathrm{~mL}$ ) (Table 4). This finding is likely to be an overestimate of the effect of recombinant factor VIIa, since four studies reporting no difference could not be incorporated into the pooled analysis because outcomes were not available as means and standard deviations. ${ }^{16,21,23,25}$ Also, there was important statistical heterogeneity $\left(I^{2}=78 \%\right)$; when we excluded studies with fewer than 50 patients, the $I^{2}$ value was $0 \%$.

Ten studies provided data on the use of red blood cell transfusion. The pooled weighted mean difference between the treatment and control arms was $-281 \mathrm{~mL}(95 \% \mathrm{CI}-433$ to $-129 \mathrm{~mL}$ ) (Table 4). This finding is again likely to be an overestimate of the effect of recombinant factor VIIa since three studies reporting no difference could not be incorporated into the pooled analysis because outcomes were not available as means and standard deviations. . $6,21,25^{1,25}$ There was evidence of significant heterogeneity $\left(I^{2}=63 \%\right)$; when we excluded studies with fewer than 50 patients, the $I^{2}$ value was $0 \%$.

Seven studies reported and contributed data on the number of patients who received transfusions. The pooled RR was 0.71 (95\% CI 0.50 to $0.99)$, with marked heterogeneity $\left(I^{2}=61 \%\right)$ (Table 4). The proportion of patients who received transfusions in the control arms ranged from $37 \% \%^{20}$ to $100 \% .^{22}$

Twelve studies contributed data on thromboembolic events. The pooled RR was 1.38 (95\% CI 0.76 to $2.51 ; I^{2}=0 \%$ ). The $95 \%$ CIs in the individual studies all included 1.0 (Figure 3). Rates of thromboembolic events in the control groups were generally low across the studies, the maximum being $2 / 10 .^{15}$

\section{Therapeutic use}

All 12 studies contributed data on mortality. The pooled RR for overall mortality was 0.90 (95\% CI 0.76 to 1.06 ), with no statistical heterogeneity $\left(I^{2}=0 \%\right)$ (Figure 2). All but one of the studies (the initial efficacy trial in spontaneous intracranial hemorrhage) yielded an RR with a 95\% CI that included 1.0. ${ }^{35}$ The rates of death in the control groups varied from $0 / 9^{32}$ to $\left.22 / 74(30 \%)\right)^{14}$

Nine trials reported on the control of bleeding. Four of them had data suitable for inclusion in

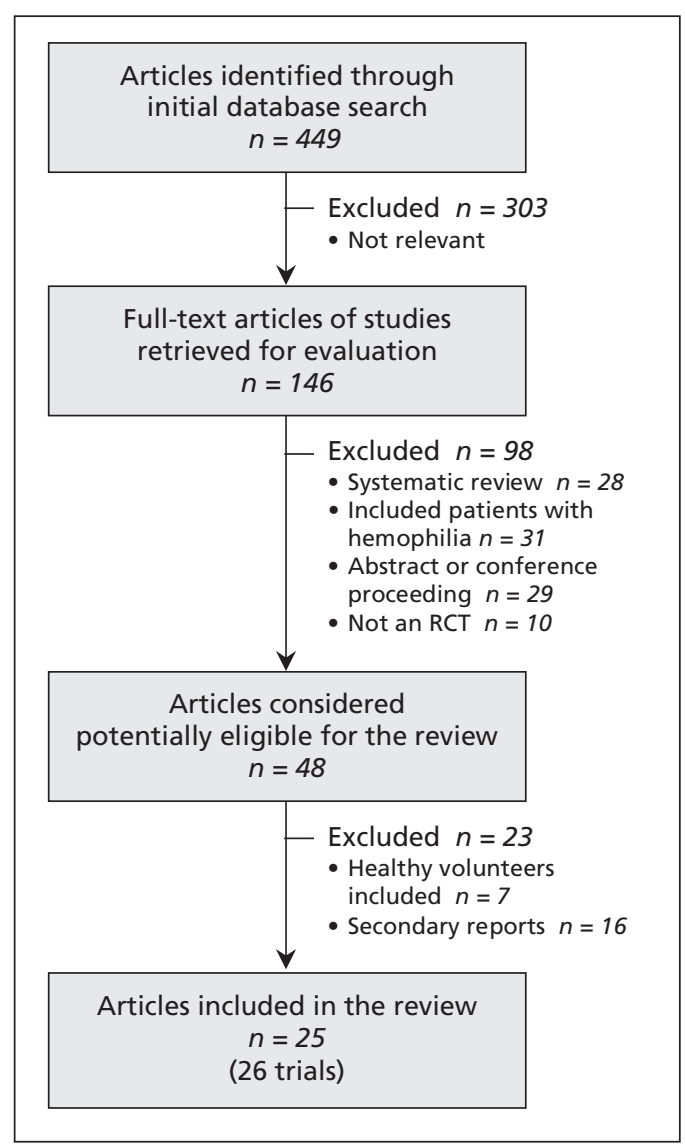

Figure 1: Selection of randomized controlled trials (RCTs). 
the pooled analysis..$^{29,30,32,33}$ The pooled RR was 1.05 (95\% CI 0.97 to $1.14 ; I^{2}=0 \%$ ) (Table 4 ). The five remaining trials were of therapeutic use of recombinant factor VIIa in intracranial hemorrhage; they measured control of bleeding in terms of hematoma growth, which could not be combined quantitatively. ${ }^{3,34-37}$ None of the safety trials $^{34,36,37}$ showed a significant reduction in their secondary outcomes of growth of volume of hemorrhage. The initial efficacy study reported a statistically significant reduction in the growth of hemorrhage volume with recombinant factor VIIa associated with reduced disability at 90 days $;^{35}$ however, the second, larger, efficacy trial ${ }^{3}$ found no significant difference between study groups in the primary outcome at 90 days.

Only four studies contributed data on the use of red blood cell transfusion. ${ }^{29-32}$ The pooled weighted mean difference was $21 \mathrm{~mL}(95 \% \mathrm{CI}$ -108 to $150 ; I^{2}=0 \%$ ) (Table 4 ). The $95 \%$ CIs in

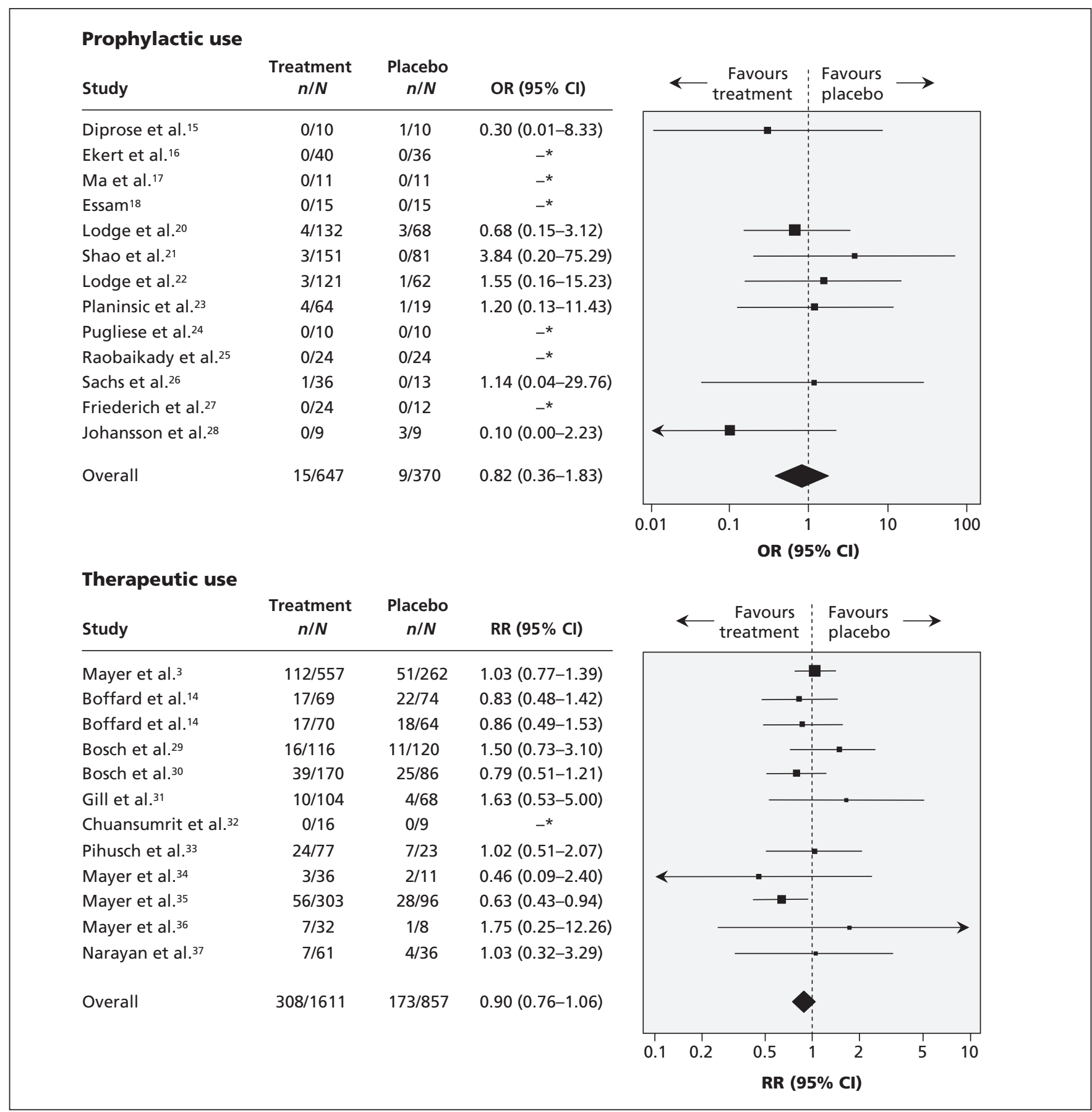

Figure 2: Pooled analysis of mortality data from randomized controlled trials of the prophylactic use (top panel) and therapeutic use (bottom panel) of recombinant factor VIla in patients without hemophilia. A value below 1.0 indicates a decreased risk of death with recombinant factor VIla. *Not estimable. $\mathrm{Cl}=$ confidence interval, $\mathrm{OR}=$ odds ratio, $\mathrm{RR}=$ risk ratio. 
each of the four studies included zero (no difference). Because data from the RCT by Boffard and colleagues ${ }^{14}$ were reported as medians and ranges, we could not incorporate them into the pooled analysis. The exclusion of these studies likely did not change the pooled weighted mean difference, because there was no significant difference in the primary outcome of number of units of red blood cells transfused for all patients at 48 hours.

Two of the 12 studies contributed data on the number of patients who received transfusions. ${ }^{31,32}$ The pooled RR was 0.81 (95\% CI 0.70 to 0.93 ; $I^{2}=0 \%$ ) (Table 4). For the trial of therapeutic use in the setting of cardiac surgery, ${ }^{31}$ we used the number of patients who received transfusions within five days; this outcome favoured recombinant factor VIIa, as compared with the cut-off of 24 hours, which did not show a statistically significant difference between the study groups.

All of the trials of therapeutic use contributed data on thromboembolic events. The pooled RR was $1.18\left(95 \%\right.$ CI 0.86 to $\left.1.62 ; I^{2}=0 \%\right)$ (Figure 3 ). The $95 \%$ CIs of the individual studies all included 1.0. Rates of thromboembolic events in the control groups were generally low across all studies, the maximum being $3 / 8 .{ }^{36}$

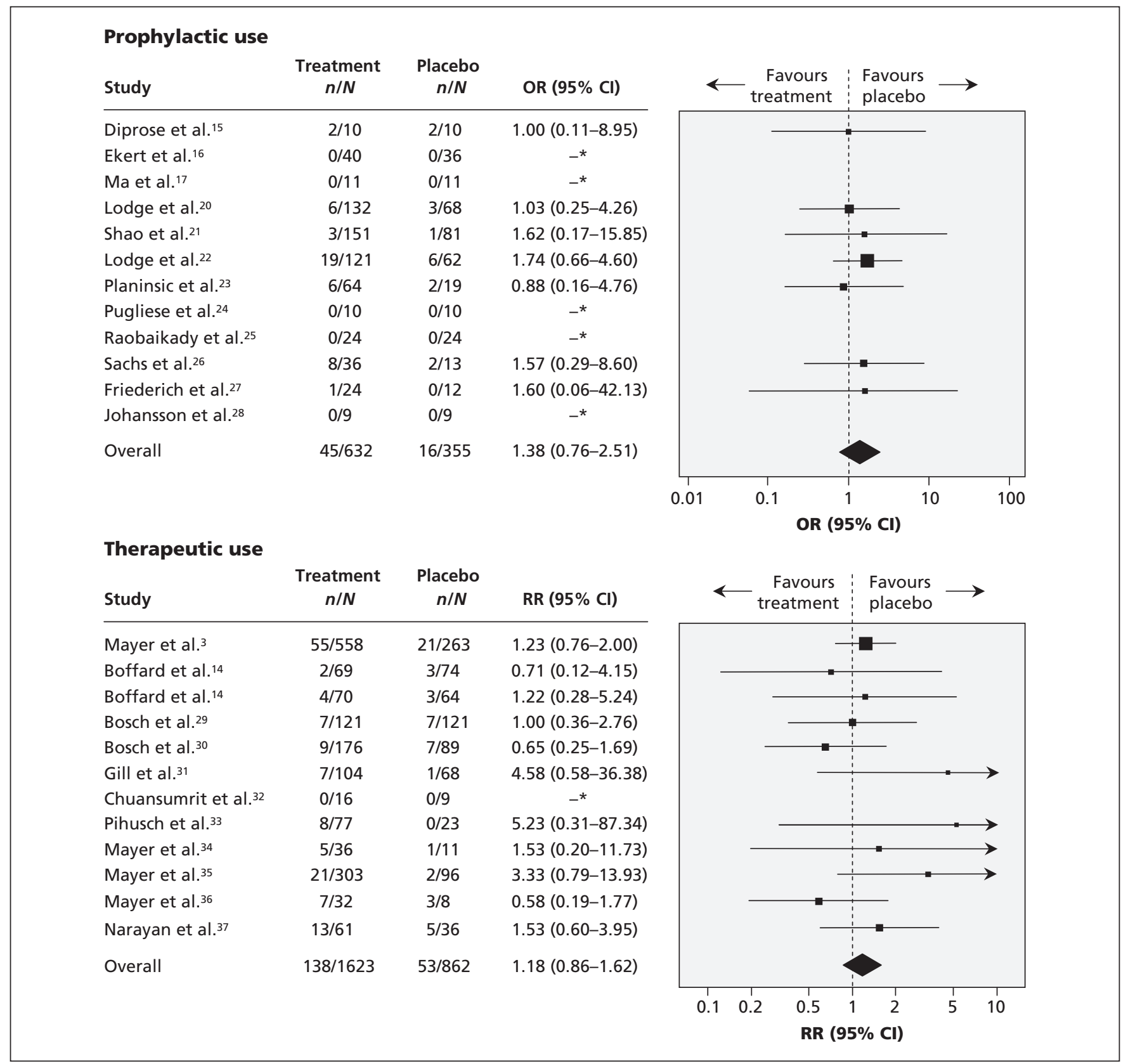

Figure 3: Pooled analysis of data on thromboembolic events from randomized controlled trials of the prophylactic use (top panel) and therapeutic use (bottom panel) of recombinant factor VIla in patients without hemophilia. A value below 1.0 indicates a decreased risk of thromboembolic event with recombinant factor VIla. *Not estimable. $\mathrm{Cl}=$ confidence interval, $\mathrm{OR}=$ odds ratio, $\mathrm{RR}=$ risk ratio. 


\section{Publication bias}

Funnel plots for the above outcomes did not show marked asymmetry (data not shown). The funnel plot for number of patients who received transfusions in the prophylactic trials suggested that small studies with an RR greater than 1.0 (favouring placebo) may be missing.

\section{Interpretation}

We included 14 RCTs on the prophylactic use $(n=1137)$ and 12 on the therapeutic use $(n=2538)$ of recombinant factor VIIa in patients without hemophilia in our review. This number of trials might be considered to be sufficient for an informative result. However, the results indicated continuing uncertainty about the magnitude of benefits and harms. In the prophylactic studies, only modest benefits favouring recombinant factor VIIa were seen in the outcomes of blood loss, requirements of red blood cell transfusion (equivalent to less than one unit of red blood cells saved) and number of patients receiving transfusions. In the therapeutic studies, there was no clear advantage of recombinant factor VIIa over placebo for the outcomes of mortality, control of bleeding and transfusion requirements. However, for mortality, the $95 \%$ CI was close to significance and may be considered clinically important (RR 0.90; 95\% CI 0.76 to 1.06). In both groups of trials, there was a trend toward increased thromboembolic events, although most RCTs excluded patients with a history of thromboembolic events. Promising results in earlier therapeutic studies were not replicated in larger trials, ${ }^{3,30,38}$ and the risk of bias assessment highlighted frequent problems in randomization, blinding and sample size.

Continued lack of clarity about the overall clinical effectiveness certainly stems from recombinant factor VIIa being genuinely less effective than was originally predicted. The trials in our review were undertaken across diverse clinical settings where different complex hemostatic pathways operate, and the expectation that recombinant factor VIIa would reverse all coagulopathy is inappropriate. ${ }^{12}$

The findings of our review are similar to those of a recent appraisal by Hsia and colleagues. ${ }^{4}$ However, we grouped the RCTs by how recombinant factor VIIa was used (prophylactic or therapeutic), because the expectations of benefit and acceptance of risk in these two situations are different. This separation and greater attention to the risk of bias in the included stud ies has emphasized the degree of uncertainty about effectiveness of off-label use of recombinant factor VIIa.

Our review raises challenges for future re- search assessing hemostatic agents, particularly concerning the choice of outcomes. Blood loss and control of bleeding are difficult to record in a standardized manner. Transfusion protocols should be supplied. The presence of a protocol was shown to decrease the effect of an intervention, as measured by reduction in use of allogeneic blood, compared with studies that had no transfusion protocol. ${ }^{39-41}$ In the studies included in our review, transfusion protocols were not always provided, and even less frequently were protocols reported for hemostatically active co-interventions such as plasma and platelet products (Tables 1 and 2). Mortality is the key outcome for therapeutic trials. However, in our review, we found that the baseline risk of death in the control groups ranged from $0 \%$ to $30 \%$, with a mean of $20 \%$. If we assumed a baseline risk of $20 \%$ and designed a superiority trial with an $\alpha$ level of 0.05 and $\beta$ level of 0.20 and an expected RR of 0.90 (equivalent to a mortality of $18 \%$ in the treatment group), the trial would require about 12000 patients to detect this difference. The cumulative number of participants evaluated to date in therapeutic trials is less than a quarter of this number.

\section{Limitations}

We were not able to obtain additional outcome data from some studies to allow them to be included in the pooled analyses. These studies generally showed no difference between recombinant factor VIIa and placebo; therefore, their inclusion might be expected to move values further toward a no-difference summary estimate. In addition, we included only published full-text articles. Although publication bias was investigated and has been previously explored, ${ }^{7}$ it is impossible to completely exclude it.

\section{Conclusion}

Clinically significant benefits of recombinant factor VIIa as a general hemostatic agent in patients without hemophilia remain unproven. Our systematic review did not show a consistent benefit of off-label use of recombinant factor VIIa in the therapeutic setting and at best only modest benefits in the prophylactic setting. Given its potential risks, off-label use of this hemostatic agent cannot be recommended, and in most instances, it should be restricted to clinical trials.

\section{References}

1. The Haemostasis Registry - How far have we come and what do we have to show for it? Victoria (Australia): Monash University; 2008. Available: www.med.monash.edu.au/epidemiology /traumaepi/workshop09.html (accessed 2010 June 20).

2. Stanworth SJ, Birchall J, Doree CJ, et al. Recombinant factor VIIa for the prevention and treatment of bleeding in patients without haemophilia. Cochrane Database Syst Rev 2007;(2): CD005011. 
3. Mayer SA, Brun NC, Begtrup K, et al. Efficacy and safety of recombinant activated factor VII for acute intracerebral hemorrhage. $N$ Engl J Med 2008;358:2127-37.

4. Hsia CC, Chin-Yee IH, McAlister VC. Use of recombinant activated factor VII in patients without hemophilia: a meta-analysis of randomized control trials. Ann Surg 2008;248:61-8.

5. Diringer MN, Skolnick BE, Mayer SA, et al. Risk of thromboembolic events in controlled trials of rFVIIa in spontaneous intracerebral hemorrhage. Stroke 2008;39:850-6.

6. Diringer MN, Skolnick BE, Mayer SA, et al. Thromboembolic events with recombinant activated factor VII in spontaneous intracerebral hemorrhage: Results from the factor seven for acute hemorrhagic stroke (FAST) trial. Stroke 2010;41:48-53.

7. Stanworth SJ, Birchall J, Doree CJ, et al. Recombinant factor VII for the prevention and treatment of bleeding in patients without haemophilia. Cochrane Database Syst Rev 2007;(2):CD005011.

8. O'Connell KA, Wood JJ, Wise RP, et al. Thromboembolic adverse events after use of recombinant human coagulation factor VIIa. JAMA 2006;295:293-8.

9. You H, Al-Shahi R. Haemostatic drug therapies for acute primary intracerebral haemorrhage. Cochrane Database Syst Rev 2006;3: CD005951.

10. Marti-Carvajal AJ, Salanti G, Marti-Carvajal PI. Human recombinant activated factor VII for upper gastrointestinal bleeding in patients with liver diseases. Cochrane Database Syst Rev 2007;(1): CD004887.

11. Ranucci M, Isgro G, Soro G, et al. Efficacy and safety of recombinant activated factor vii in major surgical procedures: systematic review and meta-analysis of randomized clinical trials. Arch Surg 2008;143:296.

12. Al-Ruzzeh S, Navia JL. The "off-label" role of recombinant factor VIIa in surgery: Is the problem deficient evidence or defective concept? J Am Coll Surg 2009;209:659-67.

13. Al-Shahi Salman R. Haemostatic drug therapies for acute spontaneous intracerebral haemorrhage. Cochrane Database Syst Rev 2009;(4):CD005951.

14. Boffard KD, Riou B, Warren B, et al. Recombinant factor VIIa as adjunctive therapy for bleeding control in severely injured trauma patients: two parallel randomized, placebo-controlled, double-blind clinical trials. J Trauma 2005;59:8.

15. Diprose P, Herbertson MJ, O'Shaughnessy D, et al. Activated recombinant factor VII after cardiopulmonary bypass reduces allogeneic transfusion in complex non-coronary cardiac surgery: Randomized double-blind placebo-controlled pilot study. Br J Anaesth 2005;95:596-602.

16. Ekert H, Brizard C, Eyers R, et al. Elective administration in infants of low-dose recombinant activated factor VII (rFVIIa) in cardiopulmonary bypass surgery for congenital heart disease does not shorten time to chest closure or reduce blood loss and need for transfusions: a randomized, double-blind, parallel group, placebo-controlled study of rFVIIa and standard haemostatic replacement therapy versus standard haemostatic replacement therapy. Blood Coagul Fibrinolysis 2006;17:389-95.

17. Ma B, Wang ZN, Zhang BR, et al. Effect of recombinant activated factor VIIa on early recovery of patients undergoing cardiac valve replacement under cardiopulmonary bypass: a randomized double-blind placebo-controlled trial. Acad J Second Military Med Univ 2006;27:1110-3.

18. Essam MA. Prophylactic administration of recombinant activated factor VII in coronary revascularization surgery. Int $J$ Anesthesiol 2007;13:10

19. Jeffers L, Chalasani N, Balart L, et al. Safety and efficacy of recombinant factor VIIa in patients with liver disease undergoing laparoscopic liver biopsy. Gastroenterology 2002;123:118-26.

20. Lodge JP, Jonas S, Oussoultzoglou E, et al. Recombinant coagulation factor VIIa in major liver resection: a randomized, placebo-controlled, double-blind clinical trial. Anesthesiology 2005;102:269-75.

21. Shao YF, Yang JM, Chau GY, et al. Safety and hemostatic effect of recombinant activated factor VII in cirrhotic patients undergoing partial hepatectomy: A multicenter, randomized, doubleblind, placebo-controlled trial. Am J Surg 2006;191:245-9.

22. Lodge JP, Jonas S, Jones RM, et al. Efficacy and safety of repeated perioperative doses of recombinant factor VIIa in liver transplantation. Liver Transpl 2005;11:973-9.

23. Planinsic RM, van der Meer J, Testa G, et al. Safety and efficacy of a single bolus administration of recombinant factor VIIa in liver transplantation due to chronic liver disease. Liver Transpl 2005;11: 895-900.

24. Pugliese F, Ruberto F, Summonti D, et al. Activated recombinant factor VII in orthotopic liver transplantation. Transplant Proc 2007;39:1883-5

25. Raobaikady R, Redman J, Ball JA, et al. Use of activated recombinant coagulation factor VII in patients undergoing reconstruc- tion surgery for traumatic fracture of pelvis or pelvis and acetabulum: A double-blind, randomized, placebo-controlled trial. $\mathrm{Br} \mathrm{J}$ Anaesth 2005;94:586-91

26. Sachs B, Delacy D, Green J, et al. Recombinant activated factor VII in spinal surgery: a multicenter, randomized, double-blind, placebocontrolled, dose-escalation trial. Spine (Phila Pa 1976) 2007;32: 2285-93.

27. Friederich PW, Henny CP, Messelink EJ, et al. Effect of recombinant activated factor VII on perioperative blood loss in patients undergoing retropubic prostatectomy: a double-blind placebo-controlled randomised trial. Lancet 2003;361:201-5.

28. Johansson PI, Eriksen K, Nielsen SL, et al. Recombinant FVIIa decreases perioperative blood transfusion requirement in burn patients undergoing excision and skin grafting — results of a single centre pilot study. Burns 2007;33:435-40.

29. Bosch J, Thabut D, Bendtsen F, et al. Recombinant factor VIIa for upper gastrointestinal bleeding in patients with cirrhosis: a randomized, double-blind trial. Gastroenterology 2004;127:1123-30.

30. Bosch J, Thabut D, Albillos A, et al. Recombinant factor VIIa for variceal bleeding in patients with advanced cirrhosis: a randomized, controlled trial. Hepatology 2008;47:1604-14.

31. Gill R, Herbertson M, Vuylsteke A, et al. Safety and efficacy of recombinant activated factor VII: a randomized placebocontrolled trial in the setting of bleeding after cardiac surgery. Circulation 2009;120:21-7.

32. Chuansumrit A, Wangruangsatid S, Lektrakul Y, et al. Control of bleeding in children with dengue hemorrhagic fever using recombinant activated factor VII: a randomized, double-blind, placebocontrolled study. Blood Coagul Fibrinolysis 2005;16:549-55.

33. Pihusch M, Bacigalupo A, Szer J, et al. Recombinant activated factor VII in treatment of bleeding complications following hematopoietic stem cell transplantation. J Thromb Haemost 2005; 3:1935-44.

34. Mayer SA, Brun NC, Broderick J, et al. Safety and feasibility of recombinant factor VIIa for acute intracerebral hemorrhage. Stroke 2005;36:74-9.

35. Mayer SA, Brun NC, Begtrup K, et al. Recombinant activated factor VII for acute intracerebral hemorrhage. N Engl J Med 2005; 352:777-85.

36. Mayer SA, Brun NC, Broderick J, et al. Recombinant activated factor VII for acute intracerebral hemorrhage: US phase IIA trial. Neurocrit Care 2006;4:206-14.

37. Narayan RK, Maas AI, Marshall LF, et al. Recombinant factor VIIA in traumatic intracerebral hemorrhage: results of a doseescalation clinical trial. Neurosurgery 2008;62:776.

38. Dutton R, Hauser C, Boffard K, et al. Scientific and logistical challenges in designing the CONTROL trial: recombinant factor VIIa in severe trauma patients with refractory bleeding. Clin Trials 2009;6:467-79.

39. Henry DA, Carless PA, Moxey AJ, et al. Pre-operative autologous donation for minimising perioperative allogeneic blood transfusion. Cochrane Database Syst Rev 2002;(2):CD003602.

40. Segal JB, Blasco-Colmenares E, Norris EJ, et al. Preoperative acute normovolemic hemodilution: a meta-analysis. Transfusion 2004;44:632-44

41. Carless PA, Henry DA, Moxey AJ, et al. Cell salvage for minimising perioperative allogeneic blood transfusion. Cochrane Database Syst Rev 2006;(4):CD001888

Affiliations: From the Department of Clinical Pathology, Sunnybrook Health Sciences Centre (Lin), and the Department of Laboratory Medicine and Pathobiology (Lin), University of Toronto, Toronto, Ont.; Haematology and Transfusion Medicine (Stanworth), National Health Service (NHS) Blood and Transplant, and Oxford Radcliffe Hospitals Trust, Oxford, UK; Haematology and Transfusion Medicine (Birchall), NHS Blood and Transplant and North Bristol NHS Trust, Bristol, UK; the Systematic Review Initiative (Doree), NHS Blood and Transplant, Oxford, UK; and Peninsula College of Medicine and Dentistry (Hyde), University of Exeter, Exeter, UK

Contributors: All of the authors contributed to the study conception and design and to the acquisition of data. Yulia Lin, Simon Stanworth, Janet Birchall and Chris Hyde contributed to the analysis and interpretation of the data and drafted the report. All of the authors critically revised the manuscript for important intellectual content and approved the final version submitted for publication.

Funding: This work was supported by the UK National Health Service Blood and Transplant and by Canadian Blood Services. 
Table 1: Characteristics of randomized controlled trials of the prophylactic use of recombinant factor VIla in patients without hemophilia (part 1 of 2)

\begin{tabular}{|c|c|c|c|c|c|c|c|}
\hline Study & $\begin{array}{l}\text { Study } \\
\text { population }\end{array}$ & $\begin{array}{l}\text { No. of initial } \\
\text { patients } \\
\text { (treatment/ } \\
\text { control) }\end{array}$ & $\begin{array}{l}\text { Dose of } \\
\text { recombinant } \\
\text { factor VIla }\end{array}$ & Control & Transfusion protocol & $\begin{array}{l}\text { Primary } \\
\text { outcome }\end{array}$ & $\begin{array}{l}\text { Secondary } \\
\text { outcomes }\end{array}$ \\
\hline $\begin{array}{l}\text { Diprose } \\
\text { et al. }{ }^{15}\end{array}$ & Cardiac surgery & $20(10 / 10)$ & $\begin{array}{l}\text { Single dose of } \\
90 \mu \mathrm{g} / \mathrm{kg} \text { after } \\
\text { protamine }\end{array}$ & Saline & $\begin{array}{l}\text { Transfusion if } \\
\text { hemoglobin }<85 \mathrm{~g} / \mathrm{L}\end{array}$ & $\begin{array}{l}\text { No. of patients } \\
\text { receiving allogeneic } \\
\text { transfusion }\end{array}$ & $\begin{array}{l}\text { Blood products } \\
\text { transfused; length } \\
\text { of stay; adverse } \\
\text { events }\end{array}$ \\
\hline $\begin{array}{l}\text { Ekert } \\
\text { et al. }{ }^{16}\end{array}$ & $\begin{array}{l}\text { Cardiac surgery } \\
\text { (infants) }\end{array}$ & $82(36 / 40)$ & $\begin{array}{l}\text { Single dose of } \\
40 \mu \mathrm{g} / \mathrm{kg} \text { after } \\
\text { protamine; } \\
\text { dose repeated } \\
\text { up to } 2 \text { times if } \\
\text { ongoing } \\
\text { bleeding }\end{array}$ & Placebo & Not stated & $\begin{array}{l}\text { Time to chest } \\
\text { closure after } \\
\text { reversal of heparin }\end{array}$ & $\begin{array}{l}\text { Blood loss within } \\
12 \mathrm{~h} \text {; blood } \\
\text { products transfused } \\
\text { within } 48 \mathrm{~h}\end{array}$ \\
\hline Ma et al. ${ }^{17}$ & Cardiac surgery & $22(11 / 11)$ & $\begin{array}{l}\text { Single dose of } \\
40 \mu \mathrm{g} / \mathrm{kg} \text { after } \\
\text { protamine }\end{array}$ & Placebo & Not stated & $\begin{array}{l}\text { No stated primary } \\
\text { outcome }\end{array}$ & $\begin{array}{l}\text { Blood loss within } \\
24 \mathrm{~h} \text {; blood } \\
\text { products transfused }\end{array}$ \\
\hline Essam $^{18}$ & Cardiac surgery & $30 \quad(15 / 15)$ & $\begin{array}{l}\text { Single dose of } \\
90 \mu \mathrm{g} / \mathrm{kg} \text { after } \\
\text { protamine }\end{array}$ & No rVIla & $\begin{array}{l}\text { Transfusion if } \\
\text { hemoglobin }<70 \mathrm{~g} / \mathrm{L}\end{array}$ & $\begin{array}{l}\text { No stated primary } \\
\text { outcome }\end{array}$ & $\begin{array}{l}\text { Blood loss within } \\
24 \mathrm{~h} \text {; blood } \\
\text { products transfused } \\
\text { within } 24 \mathrm{~h} \text {; length } \\
\text { of stay }\end{array}$ \\
\hline $\begin{array}{l}\text { Jeffers } \\
\text { et al. }{ }^{19}\end{array}$ & Liver biopsy & $66(66 / 0)$ & $\begin{array}{l}\text { Single dose of } \\
5,20,80 \text { or } \\
120 \mu \mathrm{g} / \mathrm{kg}\end{array}$ & $\begin{array}{l}\text { No } \\
\text { control } \\
\text { group }\end{array}$ & Not stated & $\begin{array}{l}\text { Time to hemostasis } \\
\text { and duration of } \\
\text { normal } \\
\text { prothrombin time }\end{array}$ & Adverse events \\
\hline $\begin{array}{l}\text { Lodge } \\
\text { et al. }\end{array}$ & $\begin{array}{l}\text { Partial } \\
\text { hepatectomy }\end{array}$ & $204(112 / 63)$ & $\begin{array}{l}20 \text { or } 80 \mu \mathrm{g} / \mathrm{kg} \text {; } \\
\text { second dose at } \\
5 \mathrm{~h} \text { if operation } \\
\text { ongoing }\end{array}$ & Placebo & $\begin{array}{l}\text { Transfusion if } \\
\text { hematocrit }<25 \% \\
\text { and platelet count } \\
<30 \times 10^{9} / \mathrm{L}\end{array}$ & $\begin{array}{l}\text { No. of patients } \\
\text { receiving allogeneic } \\
\text { transfusion within } \\
48 \mathrm{~h}\end{array}$ & $\begin{array}{l}\text { Blood loss during } \\
\text { surgery; red blood } \\
\text { cells transfused } \\
\text { within } 48 \mathrm{~h} \text {; } \\
\text { adverse events }\end{array}$ \\
\hline $\begin{array}{l}\text { Shao } \\
\text { et al. }{ }^{21}\end{array}$ & $\begin{array}{l}\text { Partial } \\
\text { hepatectomy }\end{array}$ & $235(145 / 76)$ & $\begin{array}{l}50 \text { or } 100 \\
\mu \mathrm{g} / \mathrm{kg} ; \text { dose } \\
\text { repeated every } \\
2 \mathrm{~h} \text { until end of } \\
\text { surgery } \\
\text { (maximum } 4 \\
\text { doses) }\end{array}$ & Placebo & $\begin{array}{l}\text { Transfusion if } \\
\text { blood loss }>500 \mathrm{~mL}\end{array}$ & $\begin{array}{l}\text { No. of patients } \\
\text { receiving allogeneic } \\
\text { transfusion within } \\
48 \mathrm{~h} \text {; units of red } \\
\text { blood cells } \\
\text { transfused within } \\
48 \mathrm{~h}\end{array}$ & $\begin{array}{l}\text { Blood loss during } \\
\text { surgery; blood } \\
\text { products transfused } \\
\text { within } 48 \mathrm{~h} \text {; length } \\
\text { of stay; adverse } \\
\text { events }\end{array}$ \\
\hline $\begin{array}{l}\text { Lodge } \\
\text { et al. }\end{array}$ & $\begin{array}{l}\text { Liver } \\
\text { transplantation }\end{array}$ & $209(121 / 61)$ & $\begin{array}{l}60 \text { or } 120 \\
\mu \mathrm{g} / \mathrm{kg} ; \text { dose } \\
\text { repeated every } \\
2 \text { h until end of } \\
\text { surgery }\end{array}$ & Placebo & $\begin{array}{l}\text { Transfusion if } \\
\text { hematocrit }<25 \% \text {, } \\
\text { platelet count } \\
<30 \times 10^{9} / \mathrm{L} \text { and } \\
\text { coagulation ratios } \\
>1.5 \times \text { normal }\end{array}$ & $\begin{array}{l}\text { Units of red blood } \\
\text { cells transfused } \\
\text { within } 24 \mathrm{~h}\end{array}$ & $\begin{array}{l}\text { Blood products } \\
\text { transfused within } \\
24 \mathrm{~h} \text {; blood loss } \\
\text { within } 24 \text { h; length } \\
\text { of stay; adverse } \\
\text { events }\end{array}$ \\
\hline $\begin{array}{l}\text { Planinsic } \\
\text { et al. }^{23}\end{array}$ & $\begin{array}{l}\text { Liver } \\
\text { transplantation }\end{array}$ & $87 \quad(54 / 19)$ & $\begin{array}{l}\text { Single dose of } \\
20,40 \text { or } 80 \\
\mu \mathrm{g} / \mathrm{kg}\end{array}$ & Placebo & $\begin{array}{l}\text { Transfusion if } \\
\text { hematocrit }<25 \% \text {, } \\
\text { platelet count } \\
<30 \times 10^{\circ} / \mathrm{L} \text { and } \\
\text { coagulation ratios } \\
>1.5 \times \text { normal }\end{array}$ & $\begin{array}{l}\text { Units of red blood } \\
\text { cells transfused } \\
\text { within } 24 \mathrm{~h}\end{array}$ & $\begin{array}{l}\text { Blood products } \\
\text { transfused within } \\
24 \text { h; blood loss } \\
\text { within } 24 \text { h; length } \\
\text { of stay; adverse } \\
\text { events }\end{array}$ \\
\hline $\begin{array}{l}\text { Pugliese } \\
\text { et al. }\end{array}$ & $\begin{array}{l}\text { Liver } \\
\text { transplantation }\end{array}$ & $20 \quad(10 / 10)$ & $\begin{array}{l}\text { Single dose of } \\
40 \mu \mathrm{g} / \mathrm{kg}\end{array}$ & Placebo & $\begin{array}{l}\text { Transfusion if } \\
\text { hemoglobin }<100 \mathrm{~g} / \mathrm{L} \\
\text { and INR }>1.5\end{array}$ & $\begin{array}{l}\text { No stated primary } \\
\text { outcome }\end{array}$ & $\begin{array}{l}\text { Blood products } \\
\text { transfused during } \\
\text { surgery; blood loss } \\
\text { during surgery }\end{array}$ \\
\hline $\begin{array}{l}\text { Raobaikady } \\
\text { et al. } .^{25}\end{array}$ & $\begin{array}{l}\text { Reconstructive } \\
\text { surgery for } \\
\text { traumatic pelvic } \\
\text { fractures }\end{array}$ & $48 \quad(12 / 12)$ & $\begin{array}{l}90 \mu \mathrm{g} / \mathrm{kg} \text {; } \\
\text { second dose at } \\
2 \mathrm{~h} \text { if ongoing } \\
\text { bleeding }\end{array}$ & Placebo & $\begin{array}{l}\text { Transfusion if } \\
\text { hemoglobin }<80 \mathrm{~g} / \mathrm{L}, \\
\text { platelet count } \\
<100 \times 10^{9} / \mathrm{L} \text { and } \\
\text { coagulation ratios } \\
>1.5 \times \text { normal }\end{array}$ & $\begin{array}{l}\text { Blood loss within } \\
48 \mathrm{~h}\end{array}$ & $\begin{array}{l}\text { Blood products } \\
\text { transfused within } \\
48 \mathrm{~h} \text {; no. of } \\
\text { patients receiving } \\
\text { allogeneic } \\
\text { transfusion within } \\
48 \mathrm{~h} \text {; length of } \\
\text { stay; adverse events } \\
\text { within } 30 \mathrm{~d} \text {; } \\
\text { duration of surgery }\end{array}$ \\
\hline
\end{tabular}


Table 1: Characteristics of randomized controlled trials of the prophylactic use of recombinant factor VIla in patients without hemophilia (part 2 of 2)

\begin{tabular}{|c|c|c|c|c|c|c|c|}
\hline Study & $\begin{array}{c}\text { Study } \\
\text { population }\end{array}$ & $\begin{array}{l}\text { No. of initial } \\
\text { patients } \\
\text { (treatment/ } \\
\text { control) }\end{array}$ & $\begin{array}{l}\text { Dose of } \\
\text { recombinant } \\
\text { factor VIla }\end{array}$ & Control & Transfusion protocol & $\begin{array}{l}\text { Primary } \\
\text { outcome }\end{array}$ & $\begin{array}{l}\text { Secondary } \\
\text { outcomes }\end{array}$ \\
\hline $\begin{array}{l}\text { Sachs } \\
\text { et al. }{ }^{26}\end{array}$ & $\begin{array}{l}\text { Spinal fusion } \\
\text { surgery }\end{array}$ & $60 \quad(36 / 13)$ & $\begin{array}{l}30,60 \text { or } 120 \\
\mu \mathrm{g} / \mathrm{kg} ; \text { given at } \\
\text { dosing trigger } \\
\text { and repeated at } \\
2 \mathrm{~h} \text { and } 4 \mathrm{~h}\end{array}$ & Placebo & $\begin{array}{l}\text { Transfusion if } \\
\text { hemoglobin }<90 \mathrm{~g} / \mathrm{L} \text {, } \\
\text { platelet count } \\
<75 \times 10^{9} / \mathrm{L} \text { and } \\
\text { coagulation ratios } \\
>1.5 \times \text { normal }\end{array}$ & $\begin{array}{l}\text { Adverse events } \\
\text { within } 30 \mathrm{~d} \text {; blood } \\
\text { loss during surgery }\end{array}$ & $\begin{array}{l}\text { Blood products } \\
\text { transfused during } \\
\text { surgery; duration } \\
\text { of surgery }\end{array}$ \\
\hline $\begin{array}{l}\text { Friederich } \\
\text { et al. }{ }^{27}\end{array}$ & $\begin{array}{l}\text { Retropubic } \\
\text { prostatectomy }\end{array}$ & $36(24 / 12)$ & $\begin{array}{l}\text { Single dose of } \\
20 \text { or } 40 \mu \mathrm{g} / \mathrm{kg}\end{array}$ & Saline & $\begin{array}{l}\text { Transfusion if } \\
\text { hemoglobin }<80 \mathrm{~g} / \mathrm{L} \\
\text { intraoperatively and } \\
<100 \mathrm{~g} / \mathrm{L} \\
\text { postoperatively }\end{array}$ & $\begin{array}{l}\text { Blood loss within } \\
24 \mathrm{~h} \text {; blood } \\
\text { products transfused }\end{array}$ & $\begin{array}{l}\text { Length of stay; } \\
\text { adverse events; } \\
\text { duration of surgery }\end{array}$ \\
\hline $\begin{array}{l}\text { Johansson } \\
\text { et al. }{ }^{28}\end{array}$ & $\begin{array}{l}\text { Skin excision } \\
\text { and grafting }\end{array}$ & $18 \quad(9 / 9)$ & $\begin{array}{l}40 \mu \mathrm{g} / \mathrm{kg} ; \\
\text { second dose at } \\
90 \mathrm{~min}\end{array}$ & Placebo & $\begin{array}{l}\text { Transfusion if } \\
\text { hemoglobin } \\
<100 \mathrm{~g} / \mathrm{d} \text {, platelet } \\
\text { count }<80 \times 10^{9} / \mathrm{L} ; \\
\text { transfuse fresh } \\
\text { frozen plasma in } 1: 1 \\
\text { ratio to red blood cells } \\
\text { for microvascular } \\
\text { bleeding }\end{array}$ & $\begin{array}{l}\text { Blood products } \\
\text { transfused within } \\
24 \mathrm{~h}\end{array}$ & $\begin{array}{l}\text { Length of stay; } \\
\text { mortality at } 30 \mathrm{~d} ; \\
\text { postoperative } \\
\text { complications; } \\
\text { duration of surgery }\end{array}$ \\
\hline
\end{tabular}

Table 2: Characteristics of randomized controlled trials of the therapeutic use of recombinant factor VIla in patients without hemophilia (part 1 of 2)

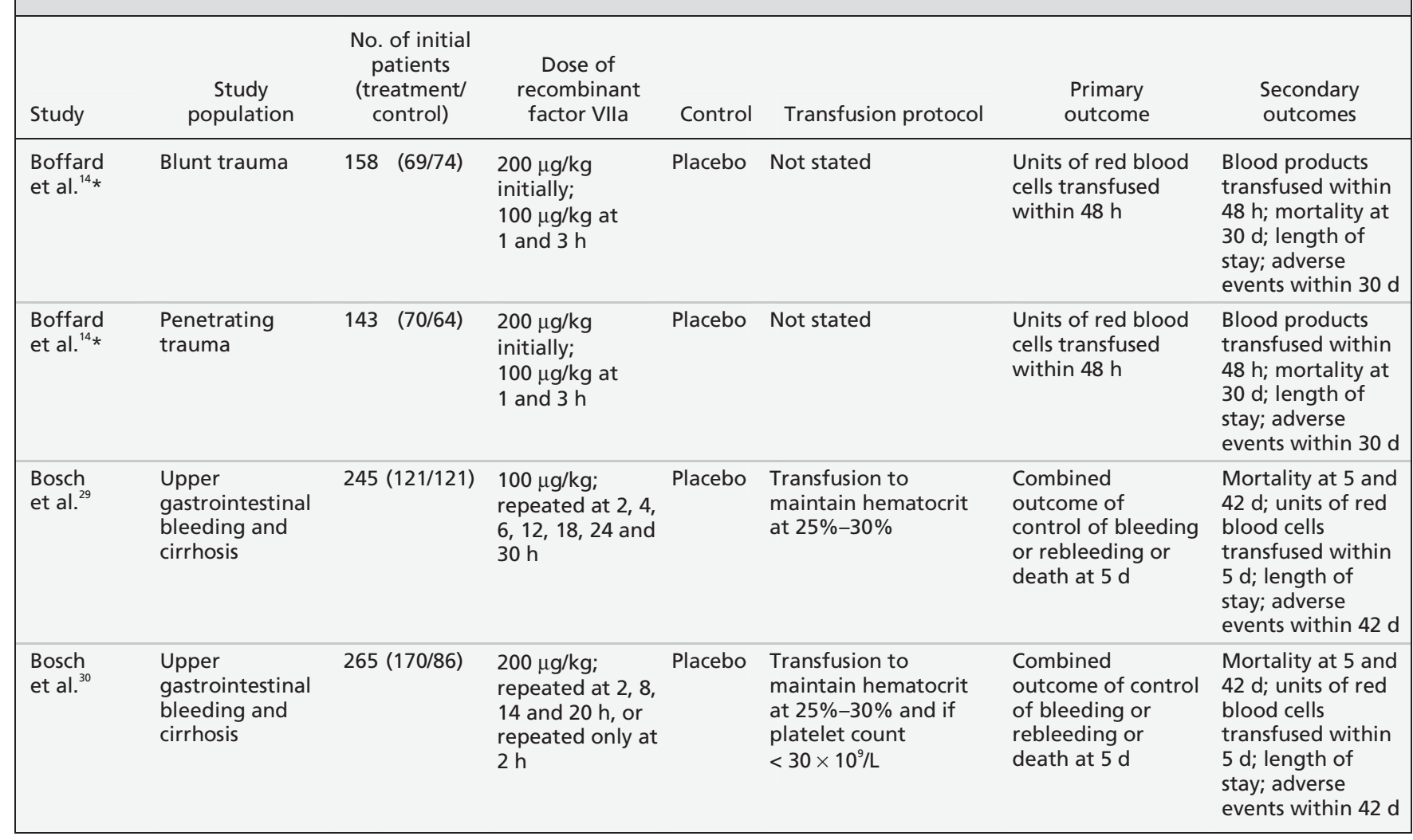




\begin{tabular}{|c|c|c|c|c|c|c|c|}
\hline Study & $\begin{array}{c}\text { Study } \\
\text { population }\end{array}$ & $\begin{array}{l}\text { No. of initial } \\
\text { patients } \\
\text { (treatment/ } \\
\text { control) }\end{array}$ & $\begin{array}{l}\text { Dose of } \\
\text { recombinant } \\
\text { factor VIla }\end{array}$ & Control & Transfusion protocol & $\begin{array}{l}\text { Primary } \\
\text { outcome }\end{array}$ & $\begin{array}{l}\text { Secondary } \\
\text { outcomes }\end{array}$ \\
\hline Gill et al. ${ }^{31}$ & $\begin{array}{l}\text { Post cardiac } \\
\text { surgery }\end{array}$ & $179(104 / 68)$ & $\begin{array}{l}\text { Single dose of } \\
40 \text { or } 80 \mu \mathrm{g} / \mathrm{kg} \\
\text { on reaching } \\
\text { prespecified } \\
\text { bleeding trigger }\end{array}$ & Placebo & $\begin{array}{l}\text { Transfusion if } \\
\text { hemoglobin }<80 \mathrm{~g} / \mathrm{L} \text {; } \\
\text { if bleeding, } \\
\text { transfusion if INR } \\
>1.5, \text { platelet } \\
<75 \times 10^{9} / \mathrm{L} \text { and } \\
\text { fibrinogen }<0.7 \mathrm{~g} / \mathrm{L}\end{array}$ & $\begin{array}{l}\text { Adverse events } \\
\text { within } 30 \mathrm{~d}\end{array}$ & $\begin{array}{l}\text { Blood loss at } 4 \mathrm{~h} \text {, } \\
24 \mathrm{~h} \text { and } 5 \mathrm{~d} \text {; } \\
\text { blood products } \\
\text { transfused within } \\
5 \mathrm{~d} \text {; reoperation } \\
\text { within } 30 \mathrm{~d}\end{array}$ \\
\hline $\begin{array}{l}\text { Chuansumrit } \\
\text { et al. }{ }^{32}\end{array}$ & $\begin{array}{l}\text { Dengue } \\
\text { hemorrhagic } \\
\text { fever (children) }\end{array}$ & $28 \quad(18 / 10)$ & $\begin{array}{l}100 \mu \mathrm{g} / \mathrm{kg} \text {; dose } \\
\text { repeated at } 30 \\
\text { min if ongoing } \\
\text { bleeding }\end{array}$ & Placebo & Not stated & $\begin{array}{l}\text { Change in bleeding } \\
\text { at } 24 \mathrm{~h}\end{array}$ & $\begin{array}{l}\text { Blood products } \\
\text { transfused within } \\
24 \mathrm{~h} \text {; adverse } \\
\text { events within } 24 \mathrm{~h}\end{array}$ \\
\hline $\begin{array}{l}\text { Pihusch } \\
\text { et al. }\end{array}$ & $\begin{array}{l}\text { Post } \\
\text { hematopoietic } \\
\text { stem-cell } \\
\text { transplantation }\end{array}$ & $100(77 / 23)$ & $\begin{array}{l}40,80 \text { or } \\
160 \mu \mathrm{g} / \mathrm{kg} \text {; dose } \\
\text { repeated every } \\
6 \mathrm{~h} \times 6\end{array}$ & Placebo & $\begin{array}{l}\text { Transfusion if } \\
\text { hemoglobin }<80 \mathrm{~g} / \mathrm{L} \\
\text { and platelet count }<20 \\
\times 10^{9} / \mathrm{L}\left(<75 \times 10^{9} / \mathrm{L} \text { in }\right. \\
\text { hemorrhagic cystitis or } \\
\text { diffuse alveolar } \\
\text { hemorrhage) }\end{array}$ & $\begin{array}{l}\text { Change in bleeding } \\
\text { at } 38 \mathrm{~h}\end{array}$ & $\begin{array}{l}\text { Blood products } \\
\text { transfused within } \\
96 \mathrm{~h} \text {; adverse } \\
\text { events within } 96 \mathrm{~h}\end{array}$ \\
\hline $\begin{array}{l}\text { Mayer } \\
\text { et al. }^{34}\end{array}$ & $\begin{array}{l}\text { Spontaneous } \\
\text { intracranial } \\
\text { hemorrhage }\end{array}$ & $48 \quad(36 / 12)$ & $\begin{array}{l}\text { Single dose of } \\
10,20,40,80 \\
120 \text { or } 160 \mu \mathrm{g} / \mathrm{kg}\end{array}$ & Placebo & Not stated & $\begin{array}{l}\text { Adverse events } \\
\text { within } 90 \mathrm{~d}\end{array}$ & $\begin{array}{l}\text { Change in volume } \\
\text { of intracranial } \\
\text { hemorrhage at } \\
24 \text { h; neurologic } \\
\text { status at } 5 \mathrm{~d} \text {; } \\
\text { disability at } 90 \mathrm{~d} \text {; } \\
\text { mortality at } 90 \mathrm{~d}\end{array}$ \\
\hline $\begin{array}{l}\text { Mayer } \\
\text { et al. }^{35}\end{array}$ & $\begin{array}{l}\text { Spontaneous } \\
\text { intracranial } \\
\text { hemorrhage }\end{array}$ & $400(303 / 96)$ & $\begin{array}{l}\text { Single dose of } \\
40,80 \mathrm{or} \\
160 \mu \mathrm{g} / \mathrm{kg}\end{array}$ & Placebo & Not stated & $\begin{array}{l}\text { Change in volume } \\
\text { of intracranial } \\
\text { hemorrhage at } \\
24 \mathrm{~h}\end{array}$ & $\begin{array}{l}\text { Disability at } 90 \mathrm{~d} \text {; } \\
\text { mortality at } 90 \mathrm{~d} \text {; } \\
\text { adverse events } \\
\text { within } 90 \mathrm{~d}\end{array}$ \\
\hline $\begin{array}{l}\text { Mayer } \\
\text { et al. }^{36}\end{array}$ & $\begin{array}{l}\text { Spontaneous } \\
\text { intracranial } \\
\text { hemorrhage }\end{array}$ & $41 \quad(32 / 8)$ & $\begin{array}{l}\text { Single dose of } \\
5,20,40 \text { or } \\
80 \mu \mathrm{g} / \mathrm{kg}\end{array}$ & Placebo & Not stated & $\begin{array}{l}\text { Adverse events } \\
\text { within } 90 \mathrm{~d}\end{array}$ & $\begin{array}{l}\text { Change in volume } \\
\text { of intracranial } \\
\text { hemorrhage at } \\
24 \mathrm{~h} \text {; neurologic } \\
\text { status at } 5 \mathrm{~d} \text {; } \\
\text { disability at } 90 \mathrm{~d} \text {; } \\
\text { mortality at } 90 \mathrm{~d}\end{array}$ \\
\hline $\begin{array}{l}\text { Mayer } \\
\text { et al. }^{3}\end{array}$ & $\begin{array}{l}\text { Spontaneous } \\
\text { intracranial } \\
\text { hemorrhage }\end{array}$ & $841(558 / 263)$ & $\begin{array}{l}\text { Single dose of } \\
20 \text { or } 80 \mu \mathrm{g} / \mathrm{kg}\end{array}$ & Placebo & Not stated & $\begin{array}{l}\text { Severe disability } \\
\text { or death within } \\
90 \mathrm{~d}\end{array}$ & $\begin{array}{l}\text { Change in volume } \\
\text { of intracranial } \\
\text { hemorrhage at } \\
24 \text { and } 72 \mathrm{~h} ; \\
\text { disability at } 90 \mathrm{~d} \text {; } \\
\text { adverse events at } \\
90 \mathrm{~d}\end{array}$ \\
\hline $\begin{array}{l}\text { Narayan } \\
\text { et al. }{ }^{37}\end{array}$ & $\begin{array}{l}\text { Traumatic } \\
\text { intracranial } \\
\text { hemorrhage }\end{array}$ & $97 \quad(61 / 36)$ & $\begin{array}{l}\text { Single dose of } \\
40,80,120,160 \\
\text { or } 200 \mu \mathrm{g} / \mathrm{kg}\end{array}$ & Placebo & Not stated & $\begin{array}{l}\text { Adverse events } \\
\text { within } 15 \mathrm{~d}\end{array}$ & $\begin{array}{l}\text { Change in volume } \\
\text { of intracranial } \\
\text { hemorrhage at } \\
24 \text { and } 72 \mathrm{~h} \text {; } \\
\text { disability at } 15 \mathrm{~d}\end{array}$ \\
\hline
\end{tabular}


Table 3: Methodologic quality of the included studies of the use of recombinant factor VIla in patients without hemophilia

\begin{tabular}{|c|c|c|c|c|c|c|}
\hline Study & $\begin{array}{l}\text { Adequate } \\
\text { sequence } \\
\text { generation }\end{array}$ & $\begin{array}{l}\text { Adequate } \\
\text { concealment } \\
\text { of allocation }\end{array}$ & $\begin{array}{l}\text { Adequate } \\
\text { blinding }\end{array}$ & $\begin{array}{c}\text { Loss to } \\
\text { follow-up, \% }\end{array}$ & $\begin{array}{l}\text { Power } \\
\text { calculation } \\
\text { performed }\end{array}$ & $\begin{array}{l}\text { Target sample } \\
\text { size achieved }\end{array}$ \\
\hline \multicolumn{7}{|l|}{ Prophylactic use (14 RCTs) } \\
\hline Diprose et al. ${ }^{15}$ & Yes & ND & Yes & 0 & Yes & No \\
\hline Ekert et al. $^{16}$ & ND & ND & Yes & 1 & No & - \\
\hline Ma et al. ${ }^{17}$ & Yes & ND & ND & 0 & No & - \\
\hline Lodge et al. ${ }^{20}$ & Yes & Yes & Yes & 9 & Yes & Yes \\
\hline Shao et al. ${ }^{21}$ & ND & ND & ND & 6 & Yes & Not stated \\
\hline Lodge et al. ${ }^{22}$ & ND & ND & ND & 13 & Yes & Yes \\
\hline Planinsic et al. ${ }^{23}$ & ND & ND & ND & 5 & Yes & Yes \\
\hline Pugliese et al. ${ }^{24}$ & ND & ND & ND & 0 & No & - \\
\hline Johansson et al. ${ }^{28}$ & Yes & ND & ND & 0 & No & - \\
\hline \multicolumn{7}{|l|}{ Therapeutic use (12 RCTs) } \\
\hline Boffard et al. ${ }^{14}$ (blunt trauma)* & ND & ND & ND & 14 & Yes & Yes \\
\hline Boffard et al. ${ }^{14}$ (penetrating trauma)* & ND & ND & ND & 9 & Yes & Yes \\
\hline Bosch et al..$^{29}$ & Yes & Yes & Yes & 3 & Yes & Yes \\
\hline Bosch et al. ${ }^{30}$ & Yes & Yes & Yes & 3 & Yes & No \\
\hline Gill et al. ${ }^{31}$ & Yes & Yes & Yes & 0 & Yes & No \\
\hline Chuansumrit et al. ${ }^{32}$ & ND & ND & Yes & 11 & No & - \\
\hline Pihusch et al. ${ }^{33}$ & Yes & Yes & Yes & 2 & Yes & Yes \\
\hline Mayer et al. ${ }^{34}$ & ND & ND & Yes & 2 & No & - \\
\hline
\end{tabular}

Table 4: Summary estimates from the pooled analysis of results from randomized controlled trials (RCTs) of the use of recombinant factor VIla in patients without hemophilia

\begin{tabular}{|c|c|c|c|c|}
\hline Outcome & $\begin{array}{l}\text { No. of } \\
\text { studies }\end{array}$ & $\begin{array}{l}\text { No. of } \\
\text { patients }\end{array}$ & $\begin{array}{l}\text { Summary estimate } \\
\qquad(95 \% \mathrm{Cl})\end{array}$ & $I^{2}$ value \\
\hline \multicolumn{5}{|l|}{ Prophylactic use (14 RCTs) } \\
\hline Mortality, RR & 13 & 1017 & $0.82(0.36$ to 1.83$)$ & 0 \\
\hline Blood loss, mL, WMD* & 8 & 505 & $-276(-411$ to -141$)$ & 78 \\
\hline Red blood cell transfusion, $\mathrm{mL}, \mathrm{WMD*}$ & 10 & 641 & $-281(-433$ to -129$)$ & 63 \\
\hline No. of patients receiving transfusion, $\mathrm{RR}^{*}$ & 7 & 765 & 0.71 (0.50 to 0.99$)$ & 61 \\
\hline Thromboembolic event, RR & 12 & 987 & 1.38 (0.76 to 2.51$)$ & 0 \\
\hline \multicolumn{5}{|l|}{ Therapeutic use (12 RCTs) } \\
\hline Mortality, RR & 12 & 2468 & $0.90(0.76$ to 1.06$)$ & 0 \\
\hline Control of bleeding, $\mathrm{RR}^{*}$ & 4 & 616 & 1.05 (0.97 to 1.14$)$ & 0 \\
\hline Red blood cell transfusion, $\mathrm{mL}, \mathrm{WMD*}$ & 4 & 590 & $21(-108$ to 150$)$ & 0 \\
\hline No. of patients receiving transfusion, $\mathrm{RR}^{*}$ & 2 & 197 & 0.81 (0.70 to 0.93 ) & 0 \\
\hline Thromboembolic event, RR & 12 & 2485 & 1.18 (0.86 to 1.62$)$ & 0 \\
\hline
\end{tabular}

